\title{
Tinjauan Yuridis Jabatan Rangkap Direksi BUMN Yang Berpengaruh Terhadap Penetapan Harga Tiket Pesawat Ditinjau dari Hukum Positif Indonesia
}

\author{
Puteri Nurjanah, Elisatris Gultom, dan Anita Afriana \\ Fakultas Hukum, Universitas Padjadjaran, Indonesia \\ Email korepondensi:puterinurjanah1@gmail.com
}

\begin{abstract}
ABSTRAK
Adanya keterkaitan antara praktik jabatan rangkap dengan penetapan harga dijelaskan dalam Peraturan KPPU No. 4 Tahun 2011 tentang Pedoman Penetapan Harga bahwa perilaku penetapan harga sebagaimana diatur dalam Pasal 5 UU No.5/1999 akan menjadi lebih mudah dilakukan apabila terdapat jabatan rangkap pada perusahaan yang saling bersaing. Persoalan ini dapat mempengaruhi secara negatif iklim persaingan usaha dan memiliki dampak serius bagi realitas dunia usaha di Indonesia. Walaupun terdapat aturan hukum yang melarang jabatan rangkap, nyatanya praktik jabatan rangkap masih sering terjadi khususnya jabatan rangkap oleh direksi badan usaha milik negara yang seharusnya berperan menyelenggarakan kemanfaatan umum dan kesejahteraan masyarakat. Berdasarkan penelitian ini ditemukan bahwa telah terjadi ketidakpastian hukum terkait jabatan rangkap direksi BUMN, yang mana dalam peraturan menteri BUMN No.3/2015 memperbolehkan seorang direksi BUMN merangkap jabatan namun hal ini bertentangan dengan peraturan diatasnya yang melarang praktik tersebut. Dengan demikian telah terjadi inkonsistensi norma antara Undang-Undang dengan peraturan pelaksananya yang melanggar ketentuan hierarki yang lebih tinggi. Implikasi dari adanya praktik jabatan rangkap Direksi BUMN ini berpotensi menimbulkan persaingan usaha tidak sehat karena penetapan harga tiket pesawat bukan bersumber dari pertimbangan nilai keekonomisan tetapi adanya kepentingan yang sama dari organ Persero.
\end{abstract}

Kata kunci: Jabatan Rangkap; Penetapan Harga; Direksi BUMN.

\section{PENDAHULUAN}

Persaingan usaha merupakan salah satu faktor penting dalam menjalankan roda perekonomian suatu negara, tidak terkecuali negara Indonesia. Lebih lanjut, persaingan usaha dapat mempengaruhi setiap kebijakan terutama berkaitan dengan perdagangan, industri, iklim usaha yang kondusif, kesempatan berusaha, efisiensi, kepentingan umum, kesejahteraan rakyat, serta kebijakan lainnya (Anna Maria Tri Anggraini, 2017, p. 24). Dalam implementasinya, persaingan usaha yang sehat diwujudkan dalam dua hal, yaitu melalui penegakan hukum persaingan usaha dan melalui kebijakan persaingan yang kondusif terhadap perkembangan sektor ekonomi (Hermansyah, 2009, p. 15). Hal tersebut mendorong para legislatif di Indonesia pada masanya mengesahkan Undang-Undang Nomor 5 Tahun 1999 tentang Larangan Praktek Monopoli dan Persaingan Usaha Tidak Sehat (selanjutnya disebut UU No. 5/1999) guna menjaga kepentingan umum dan meningkatkan efisiensi ekonomi nasional sebagai salah satu upaya untuk meningkatkan kesejahteraan rakyat.

Namun tujuan dari kepentingan umum (public interest) dan efisiensi ekonomi (economic efficiency) sebagaimana diatur dalam peraturan a quo tidak akan terwujud jika pelaku usaha melakukan kecurangan atau ketidakjujuran dalam usahanya, salah satunya dengan penetapan harga. Perjanjian penetapan harga adalah kesepakatan antara penjual untuk menaikkan atau menetapkan harga, untuk membatasi persaingan antar perusahaan dan mencapai keuntungan 
yang lebih tinggi (Margono, 2009, p. 84). Perjanjian penetapan harga tersebut telah diatur secara tegas dalam Pasal 5 UU No. 5/1999, yang manyatakan bahwa pelaku usaha dilarang mengadakan perjanjian dengan pesaing usahanya untuk menentukan harga barang dan/atau jasa yang harus dibayar oleh konsumen atau pelanggan dalam pasar yang sama. Dengan kata lain, adanya larangan atas perjanjian penetapan harga ini dikarenakan terdapat kordinasi antara dua subjek hukum yaitu pelaku usaha dan pelaku usaha pesaing secara bersama-sama yang mengakibatkan harga menjadi lebih tinggi dari harga normal, sehingga tidak berlaku hukum pasar terkait harga yang terbentuk dari penawaran dan permintaan.

Dalam hukum ekonomi, perilaku penetapan harga antar pelaku usaha yang bersaing merupakan bentuk kolusi. Kolusi mengacu pada situasi di mana pelaku usaha di pasar mengoordinasikan tindakannya dengan tujuan untuk mendapatkan keuntungan yang lebih tinggi. Koordinasi dalam kolusi digunakan untuk menyepakati beberapa hal, antara lain penetapan harga tertentu yang lebih tinggi dari harga yang diperoleh melalui mekanisme persaingan, penetapan jumlah tertentu yang lebih rendah dari pada situasi persaingan, serta peluang untuk berbagi pasar (Usman, 2013, p. 212).

Penetapan harga dapat terjadi melalui skenario yang berbeda apabila dilakukan oleh satu subjek hukum tanpa koordinasi maupun perjanjian, yaitu dengan penyalahgunaan posisi dominan seperti jabatan rangkap. Secara umum, pengertian jabatan rangkap adalah praktik dimana rangkap jabatan kedudukan dan/atau komisaris dari dua perusahaan atau lebih yang dapat membentuk hubungan istimewa/khusus tersebut akan berdampak negatif terhadap iklim persaingan usaha yang sehat, baik secara horizontal, vertikal maupun konglomerasi. Keterkaitan antara praktik jabatan rangkap dengan penetapan harga ini juga dijelaskan dalam Peraturan Komisi Pengawas Persaingan Usaha Nomor 4 Tahun 2011 tentang Pedoman Penetapan Harga (selanjutnya disebut Perkom No.4/2011) bahwa perilaku penetapan harga akan lebih mudah dilakukan jika terdapat jabatan rangkap dalam perusahaan yang saling bersaing. Posisi ini pada akhirnya akan memudahkan proses penetapan harga.

Meskipun ketentuan mengenai jabatan rangkap tidak diatur secara spesifik dalam Undang-Undang Nomor 40 Tahun 2007 tentang Perseroan Terbatas j.o. Undang-Undang Nomor 11 Tahun 2020 tentang Cipta Kerja (selanjutnya disebut UU No. 40/2007), namun dalam peraturan sederajat lain, praktik jabatan rangkap ini telah dilarang secara tegas dalam Pasal 26 UU No. 5/1999, yang menyatakan bahwa: "Seseorang yang menduduki jabatan sebagai direksi atau komisaris dari suatu perusahaan, pada waktu yang bersamaan dilarang merangkap menjadi direksi atau komisaris pada perusahaan lain, apabila perusahaanperusahaan tersebut:

a. berada dalam pasar bersangkutan yang sama; atau

b. memiliki keterkaitan yang erat dalam bidang dan atau jenis usaha; atau

c. secara bersama dapat menguasai pangsa pasar barang dan atau jasa tertentu, yang dapat mengakibatkan terjadinya praktek monopoli dan atau persaingan usaha tidak sehat."

Tidak hanya berlaku bagi Perseroan Terbatas milik swasta, larangan jabatan rangkap juga berlaku bagi Badan Usaha Milik Negara (BUMN) berbentuk Perseroan Terbatas (PT), yang mana pengaturan terkait larangan jabatan rangkap dapat ditemukan dalam Pasal 25, Pasal 33, Pasal 53, Pasal 62 Undang-Undang Nomor 19 Tahun 2003 tentang Badan Usaha Milik Negara j.o Undang-Undang Nomor 11 Tahun 2020 tentang Cipta Kerja (selanjutnya disebut UU No. 19/2003).

Berbanding terbalik dengan peraturan-peraturan a quo, pengecualian terkait larangan jabatan rangkap termaktub dalam peraturan pelaksana Direksi BUMN, yaitu pada BAB IV huruf A angka 6 huruf b Lampiran Peraturan Menteri BUMN Nomor PER-03/MBU/02/2015 Tentang Persyaratan, Tata Cara Pengangkatan dan Pemberhentian Anggota Direksi Badan Usaha Milik Negara (selanjutnya disebut Permen BUMN No. 3/2015) yang menyatakan bahwa 
selain rangkap jabatan sebagaimana dimaksud pada angka 5, anggota Direksi dilarang merangkap jabatan sebagai anggota Dewan Komisaris pada perusahaan lain, kecuali anggota Dewan Komisaris pada perusahaan lain untuk mewakili/memperjuangkan kepentingan BUMN sepanjang mendapat ijin dari Menteri. Lebih lanjut terdapat peraturan yang memperbolehkan jabatan rangkap yaitu Pasal 6 Peraturan Otoritas Jasa Keuangan Nomor 33/POJK.04/2014 (selanjutnya disebut Peraturan OJK No. 33/2014) tentang Direksi dan Dewan Komisaris Emiten Atau Perusahaan Publik, yang menyatakan Anggota Direksi dapat merangkap jabatan, sepanjang tidak bertentangan dengan peraturan perundang-undangan lainnya. Oleh karena itu dapat disimpulkan bahwa secara normatif terdapat inskonsistensi norma peraturan terkait larangan jabatan rangkap khususnya pada BUMN (Persero).

Inkonsistensi norma terkait jabatan rangkap oleh direksi BUMN berpotensi menyebabkan persaingan usaha tidak sehat seperti penetapan harga. Hal ini sebagaimana Praktik Jabatan Rangkap oleh Direksi Persero BUMN pada kasus yang terjadi antara PT. Garuda Indonesia (Persero) Tbk melalui anak usahanya PT. Citilink Indonesia (Citilink) pada 9 November 2018 yang telah mengambil alih pengelolaan operasional dan finansial dari PT. Sriwijaya Air (Sriwijaya) yang terdiri dari maskapai Sriwijaya dan NAM Air melalui perjanjian Kerjasama Operasional (KSO). Bahwa berkaitan dengan kerjasama tersebut maka Garuda Group secara langsung maupun tidak langsung telah melakukan pengendalian secara operasional terhadap kegiatan usaha Sriwijaya Group dengan menunjuk perwakilan ke dalam susunan Direksi Sriwijaya Group. Kasus ini cukup menarik perhatian publik secara luas karena berkaitan erat dengan isu kenaikan harga tiket pesawat secara tidak wajar yang terjadi di tahun 2019 hingga berdampak pada terbitnya petisi daring dalam laman change.org berjudul "Turunkan Harga Tiket Pesawat Domestik Indonesia" yang menuai berbagai polemik di masyarakat (Fadhil, 2019).

Komisi Pengawas Persaingan Usaha (KPPU) menilai dalam implementasi perjanjian KSO tersebut selain adanya kerja sama operasional dan pemasaran, juga terdapat praktik jabatan rangkap yang terjadi pasca pelaksanaan perjanjian KSO. Diketahui bahwa struktur dewan komisaris Sriwijaya Air setelah itupun berubah, 3 (tiga) direksi Garuda Indonesia terbukti merangkap jabatan dengan masuk ke dalam jajaran Dewan Komisaris Sriwijaya Air. Menurut KPPU, praktik jabatan rangkap yang terjadi ini kemudian dapat menimbulkan kegiatan anti-persaingan karena keberadaan tiga direksi yang menjabat di dua perusahaan pada pasar bersangkutan yang sama tersebut berpotensi dapat mengatur harga jual kepasar sehingga bisa berujung pada persoalan kenaikan harga tiket pesawat yang meresahkan masyarakat. Pada proses penyelidikan selanjutnya oleh KPPU ditemukan fakta bahwa rangkap jabatan yang dilakukan direksi Garuda tersebut ternyata dilakukan atas arahan pemerintah atau khususnya Kementerian BUMN melalui Peraturan Menteri (Permen) (Adhi Wicaksono, 2019).

Direktur Investigasi KPPU, Gopperera Panggabean mengatakan bahwa dari sisi Permen yang dimaksud dijelaskan bahwa direksi BUMN dapat menduduki jabatan lainnya selama tidak berbenturan dengan kepentingan BUMN. Disisi lain KPPU sebelumnya juga mengatakan bahwa Permen BUMN tersebut seharusnya tidak boleh melanggar ketentuan yang lebih tinggi, dalam hal ini UU No.5 tahun 1999 tentang Larangan Praktek Monopoli dan Persaingan Usaha Tidak Sehat (Makki, 2019). Berdasarkan uraian permasalahan di atas, rumusan permasalahan yang akan dibahas dalam penelitian ini yaitu bagaimana kedudukan peraturan terkait praktik jabatan rangkap direksi BUMN (Persero) ditinjau dari hukum positif Indonesia dan bagaimana implikasi praktik jabatan rangkap direksi BUMN (Persero) terhadap penetapan harga harga tiket pesawat ditinjau dari hukum positif Indonesia. 


\section{METODE PENELITIAN}

Jenis penelitian yang digunakan dalam penelitian ini ialah pendekatan yuridis normatif (legal reseacrh), yaitu penelitian hukum yang dilakukan dengan cara melakukan penelusuran terhadap peraturan dan literatur yang berkaitan dengan permasalahan yang diteliti (Mamudji, 2001, pp. 13-14). Adapun metode pendekatan dalam penelitian ini dengan menggunakan pendekatan peraturan perundang-undangan (statue approach) yang dilakukan dengan menelaah semua peraturan perundang-undangan dan regulasi yang serkaitan dengan masalah yang diteliti yakni terkait praktik jabatan rangkap direksi BUMN terhadap pelanggaran perjanjian penetapan harga. Selain itu juga menggunakan pendekatan konseptual (conceptual approach) dengan menafsirkan hal-hal teoritis yang berkaitan dengan asas, konsepsi, doktrin dan norma hukum yang berkaitan dengan pengaturan praktek rangkap jabatan dan perjanjian penetapan harga berdasarkan hukum positif Indonesia. Terakhir, menggunakan pendekatan kasus (case approach), yaitu dengan melakukan studi kasus yang berkaitan dengan masalah yang diteliti.

Sumber data dalam penelitian ini menggunakan bahan hukum primer dan bahan hukum sekunder. Bahan hukum primer adalah segala aturan hukum yang secara resmi dibentuk oleh suatu lembaga negara, dan/atau lembaga pemerintah, yang pelaksanaannya akan ditegakkan berdasarkan kekuasaan yang dilaksanakan secara resmi oleh aparatur negara. Bahan hukum primer yang dimaksud dalam penelitian ini berupa perundang-undangan yang mengatur terkait jabatan rangkap direksi dan perjanjian penetapan harga. Sedangkan bahan hukum sekunder berupa segala keterangan tentang peraturan perundang-undangan yang berlaku atau telah berlaku di suatu negara (Wignjosoebroto, 2013, p. 81). Dalam penelitian ini, bahan hukum yang dimaksud terdiri dari buku, jurnal, dan hasil penelitian terkait jabatan rangkap direksi BUMN dan perjanjian penetapan harga.

\section{HASIL PENELITIAN DAN PEMBAHASAN}

\section{Kedudukan Peraturan Terkait Praktik Jabatan Rangkap oleh Direksi BUMN (Persero) Ditinjau dari Hukum Positif Indonesia}

Jabatan rangkap adalah situasi dimana seseorang menduduki suatu jabatan (anggota dewan) dan/atau komisaris pada dua atau lebih perusahaan atau menjadi wakil dari dua atau lebih perusahaan. Jabatan rangkap ini dapat terjadi antara perusahaan induk, satu perusahaan induk dengan anak perusahaan lainnya atau anak perusahaan dari berbagai perusahaan induk, baik di pasar yang sama (horizontal) maupun di pasar yang berbeda (vertikal). Kondisi ini akan menciptakan hubungan khusus atau istimewa antara perusahaan yang merangkap jabatan atau komisaris yang umumnya terkait dengan hubungan keuangan dan kepemilikan bersama atas saham. Oleh karena itu, jabatan rangkap ini memiliki peluang untuk menguasai pasar tertentu melalui posisi dominannya, seperti mengatur pemasaran, jumlah produksi, penetapan harga (price fixing), serta strategi lain yang menghambat persaingan usaha sehat.

Praktik jabatan rangkap merupakan persoalan tersendiri dalam menjalankan usaha pada perseroan terbatas, kenyataannya di beberapa perusahaan khususnya di perusahaan swasta masih terdapat jabatan rangkap yang dilakukan, kondisi ini terjadi karena dilatarbelakangi ketentuan yang tidak pasti (inkonsisten), bahkan UU No. 40/2007 tidak secara tegas mengatur terkait jabatan rangkap. Problematika mengenai inkonsistensi mengenai jabatan rangkap menjadi penting bila berkaitan dengan BUMN dikarenakan perannya sebagai pelopor dan/atau perintis dalam berbagai sektor usaha sehingga menjadi panutan bagi perusahaan swasta. Merujuk pada Pasal 93 dan Pasal 110 UU No. 40/2007 terkait persyaratan pengangkatan direksi dan komisaris, yang mana peraturan tersebut tidak menyebutkan mengenai jabatan rangkap. Meskipun demikian, UU No.40/2007 tidak mengurangi kemungkinan terdapat peraturan lain 
yang melarang atau membatasi jabatan rangkap tersebut (lex specialis derogate lex generalis). Pengaturan mengenai jabatan rangkap direksi BUMN secara khusus disebutkan dalam beberapa peraturan perundang-undangan, antara lain UU No. 5/1999, UU No. 19/2003, Undang-Undang Nomor 25 Tahun 2009 Tentang Pelayanan Publik (selanjutnya disebut UU No. 25/2009), Permen BUMN No. 3/2015, dan Peraturan OJK No. 33/2014.

Pertama, pengaturan jabatan rangkap dalam UU No. 5/1999, secara umum praktik jabatan rangkap yang mengakibatkan terjadinya praktik monopoli dan persaingan usaha tidak sehat sebagaimana dilarang dalam Pasal 26 yang menyatakan bahwa: "Seseorang yang menduduki jabatan sebagai direksi atau komisaris dari suatu perusahaan, pada waktu yang bersamaan dilarang merangkap menjadi direksi atau komisaris pada perusahaan lain, apabila perusahaan-perusahaan tersebut:

a. Berada dalam pasar bersangkutan yang sama; atau

b. Memiliki keterkaitan yang erat dalam bidang atau jenis usaha; atau

c. Secara bersama dapat menguasai pangsa pasar barang dan atau jasa tertentu, yang dapat mengakibatkan terjadinya praktek monopoli dan atau persaingan usaha tidak sehat."

Secara khusus, praktik jabatan rangkap pada perusahaan yang berada dalam pasar bersangkutan yang sama (memiliki kaitan substitusi yang kuat) dapat menguasai pasar tertentu serta berpotensi untuk menyalahgunakan posisi dominannya. Jabatan rangkap juga terjadi antar dua atau lebih perusahaan dalam jalur vertikal (hulu-hilir) dan atau yang memiliki kaitan erat dalam proses produksi/distribusi.

Kedua $_{2}$ pengaturan jabatan rangkap dalam UU No. 19/2003 diatur dalam Pasal 25 dan Pasal 33, yang mana secara tegas melarang anggota direksi BUMN untuk merangkap jabatan. Pasal 25 menyatakan: "Anggota Direksi dilarang memangku jabatan rangkap sebagai:

a. anggota Direksi pada BUMN, badan usaha milik daerah, badanusaha milik swasta, dan jabatan lain yang dapat menimbulkan benturan kepentingan;

b. jabatan struktural dan fungsional lainnya pada instansi/lembaga pemerintah pusat dan daerah; dan/atau

c. jabatan lainnya sesuai dengan ketentuan peraturan perundang-undangan.”

Sedangkan di dalam Pasal 33 dinyatakan: "Anggota Komisaris dilarang memangku jabatan rangkap sebagai:

a. anggota Direksi pada BUMN, badan usaha milik daerah, badanusaha milik swasta, dan jabatan lain yang dapat menimbulkan benturan kepentingan; dan/atau

b. jabatan lainnya sesuai dengan ketentuan peraturan perundang-undangan."

Ketiga, pengaturan jabatan rangkap dalam UU No. 25/2009 diatur dalam Pasal 17 huruf a, yang turut melarang praktik jabatan rangkap oleh Pelaksana pelayanan publik yaitu pejabat yang bekerja dalam organisasi yang melakukan tindakan pelayanan publik. Pada Pasal 9 huruf b Peraturan Pemerintah Nomor 96 Tahun 2012 tentang Pelaksanaan UU No. 25/2009, menyebutkan BUMN termasuk sebagai salah satu kualifikasi penyelenggara pelayanan publik. Adapun Pasal 17 menyebutkan bahwa pelaksana pelayanan publik dilarang: "Merangkap sebagai komisaris atau pengurus organisasi usaha bagi pelaksana yang berasal dari instansi pemerintah, badan usaha milik negara, dan badan usaha milik daerah". Lebih lanjut, apabila terdapat pelanggaran, sesuai dengan Pasal 54 ayat (7) anggota direksi dan anggota dewan komisaris yang bersangkutan akan dikenakan sanksi berupa pembebasan dari jabatannya.

Keempat, pengaturan jabatan rangkap dalam Permen BUMN No. 3/2015, diatur dalam Lampiran BAB IV huruf A angka 4 huruf c, angka 5, dan angka 6, yang mana peraturan tersebut memberikan pengecualian terhadap larangan jabatan rangkap Direksi BUMN. Dimana peraturan tersebut adalah sebagai berikut: 
“4. Jabatan Direksi berakhir apabila: c. tidak lagi memenuhi persyaratan sebagai Direksi berdasarkan ketentuan anggaran dasar dan peraturan perundang-undangan termasuk rangkap jabatan yang dilarang dan pengunduran diri."

"5. Rangkap jabatan yang dilarang sebagaimana dimaksud pada angka 4 huruf c antara lain sebagai berikut:

a. Direksi pada BUMN, BUMD dan badan usaha swasta;

b. Dewan komisaris/Dewan Pengawas pada BUMN;

c. Jabatan struktural dan fungsional lainnya pada instansi/lembaga pemerintah pusat dan/atau daerah;

d. Jabatan lainnya sesuai dengan ketentuan dalam peraturan perundang-undangan;

e. Pengurus partai politik, anggota legislatif dan/atau kepala daerah/wakil kepala daerah; dan/atau

f. Jabatan lain yang dapat menimbulkan benturan kepentingan.

g. Menjadi calon legislatif atau calon kepala daerah/wakil kepala daerah.

h. Diberhentikan berdasarkan keputusan RUPS secara fisik, keputusan Menteri selaku RUPS, atau keputusan seluruh pemegang saham secara sirkuler."

Namun dalam angka 6 disebutkan terdapat pengecualian, yaitu:

“6. Selain jabatan rangkap sebagaimana dimaksud pada angka 5, anggota Direksi dilarang memangku jabatan rangkap sebagai anggota Dewan Komisaris pada perusahaan lain, kecuali :

a. Anggota Dewan Komisaris pada anak perusahaan/perusahaan patungan BUMN yang bersangkutan, dengan ketentuan hanya berhak atas akumulasi penghasilan sebagai anggota Dewan Komisaris pada satu atau lebih anak perusahaan/perusahaan patungan maksimal sebesar $30 \%$ (tiga puluh persen) dari gaji Anggota Direksi yang bersangkutan di BUMN, sedangkan penghasilan lain/selebihnya diserahkan menjadi penghasilan BUMN yang bersangkutan.

b. Anggota Dewan Komisaris pada perusahaan lain untuk mewakili/memperjuangkan kepentingan BUMN sepanjang memperoleh ijin dari Menteri.”

$\underline{\text { Kelima, }}$ pengaturan jabatan rangkap dalam Peraturan OJK No. 33/2014, tercantum dalam Pasal 6 dan Pasal 24. Berbeda dengan keempat peraturan sebelumnya Peraturan OJK ini menyatakan baik anggota direksi maupun anggota dewan komisaris dapat merangkap jabatan pada emiten atau perusahaan publik lain. Dimana Pasal 6 peraturan ini menyatakan sebagai berikut:

(1) Anggota direksi dapat merangkap jabatan sebagai:
a. Anggota direksi paling banyak pada 1 (satu) Emiten atau Perusahaan Publik lain;
b. Anggota Dewan Direksi paling banyak pada 3 (tiga) Emiten atau Perusahaan Publik lain; dan/atau
c. Anggota komite paling banyak pada 5 (lima) komite di Emiten atau Perusahaan Publik dimana yang bersangkutan juga menjabat sebagai anggota Direksi atau anggota Dewan Komisaris.

(2) Rangkap jabatan sebagaimana dimaksud pada ayat (1) hanya dapat dilakukan sepanjang tidak bertentangan dengan peraturan perundang-undangan lainnya.

(3) Dalam hal terdapat peraturan perundang-undangan lainnya yang mengatur ketentuan mengenai rangkap jabatan yang berbeda dengan ketentuan dalam Peraturan Otoritas Jasa Keuangan ini, berlaku ketentuan yang mengatur lebih ketat.” Selanjutnya jabatan rangkap juga diatur di dalam Pasal 24 peraturan ini:

(1) Anggota dewan komisaris dapat merangkap jabatan sebagai:

a. anggota Direksi paling banyak pada 2 (dua) Emiten atau Perusahaan Publik lain; dan 
b. anggota Dewan Komisaris paling banyak pada 2 (dua) Emiten atau Perusahaan Publik lain.

(2) Dalam hal anggota dewan komisaris tidak merangkap jabatan sebagai anggota direksi, anggota dewan komisaris yang bersangkutan dapat merangkap jabatan sebagai anggota dewan komisaris paling banyak pada 4 (empat) emiten atau perusahaan publik lain.

(3) Anggota dewan komisaris dapat merangkap sebagai anggota komite paling banyak pada 5 (lima) komite di emiten atau perusahaan publik dimana yang bersangkutan juga menjabat sebagai anggota direksi atau anggota dewan komisaris."

Berdasarkan lima peraturan a quo maka terlihat inkonsistensi norma, yaitu munculnya pengecualian jabatan rangkap berupa ijin menteri pada Permen BUMN No. 3/2015, bahkan adanya jabatan rangkap yang diperbolehkan pada Peraturan OJK No. 33/2014, padahal pengecualian tersebut sama sekali tidak diatur dalam UU No. 5/1999, UU No. 19/2003 dan UU No. 25/2009. Oleh karena itu, diperlukan suatu kepastian hukum untuk kedudukan dari tiap peraturan perundang-undangan yang ada untuk menjawab peraturan mana yang seharusnya dipakai sebagai landasan dari legalitas jabatan rangkap Direksi BUMN.

Berdasarkan teori hukum menurut Nurhasan Ismail terciptanya kepastian hukum dalam peraturan perundang-undangan memerlukan persyaratan yang berkaitan dengan struktur internal norma hukum itu sendiri (Ismail, 2007, p. 39). Dengan demikian dapat dijabarkan bahwa untuk menciptakan ketentuan hukum, maka memiliki syarat-syarat harus dipenuhi sebagai parameter peraturan perundang-undangan, diantaranya ialah: 1) kejelasan konsep yang digunakan; 2) kejelasan hierarki kewenangan dari lembaga pembentuk peraturan perundangundangan; 3) adanya konsistensi norma hukum peraturan perundang-undangan tertentu.

Menurut Hans Nawiasky, salah satu murid Hans Kelsen, ia mengembangkan teori hierarki norma gurunya dalam kaitannya dengan negara. Hans Kelsen dalam bukunya: allgemeine Rechtslehre berpendapat bahwa norma hukum yang lebih rendah berlaku, berasal, dan didasarkan pada norma yang lebih tinggi, dan norma yang lebih tinggi juga berasal dari norma yang lebih tinggi dan seterusnya sampai berhenti pada norma tertinggi, disebut sebagai norma dasar negara. Oleh karena itu, hukum selalu dibentuk dan dihapuskan oleh lembagalembaga yang membentuknya, berdasarkan norma yang lebih tinggi sehingga norma yang lebih rendah (inferior) dapat dibentuk berdasarkan norma yang lebih tinggi (superior). Pada akhirnya hukum menjadi berjenjang dan berlapis-lapis membentuk hierarki. Hans Nawiasky melalui teori yang disebut dengan "theorie von stufenufbau der rechtsordnung" (Astawa, 2008, p. 38). Teori ini memberikan penjelasan susunan norma sebagai berikut :

1. Norma fundamental negara (staatsfundamentalnorm);

2. Aturan-aturan dasar negara/aturan pokok negara (staats grundgezetz);

3. Undang-Undang (formal) (formallegezetz);

4. Peraturan pelaksanaan serta Peraturan otonom (verordnung \& autonomi satzung).

Kelompok-kelompok norma hukum ini selalu memiliki susunan norma hukum di setiap negara meskipun memiliki istilah yang berbeda atau jumlah norma yang berbeda di setiap kelompoknya. Hubungan antar norma yang mengatur pembentukan norma lain dapat digambarkan sebagai hubungan antara "Superordinasi" dan "Subordinasi" yang bersifat khusus, yaitu:

i. $\quad$ Norma yang menentukan terbentuknya norma lain adalah norma yang lebih tinggi;

ii. Norma yang dibentuk menurut suatu peraturan adalah norma yang lebih rendah.

iii. Tatanan hukum, khususnya tata hukum yang dipersonifikasikan dalam bentuk Negara, bukan merupakan sistem norma yang hanya saling berkoordinasi yang berdiri sejajar, melainkan merupakan tatanan norma dari tingkat yang berbeda.

Hierarki peraturan perundang-undangan sebagaimana merujuk pada Pasal 7 ayat (1) Undang-Undang Nomor 15 Tahun 2019 tentang Perubahan atas Undang-Undang Nomor 12 
Tahun 2011 tentang Pembentukan Peraturan Perundang-undangan (selanjutnya disebut UU No.15/2019) yang terdiri atas:

a. Undang-Undang Dasar Negara Republik Indonesia Tahun 1945;

b. Ketetapan Majelis Permusyawaratan Rakyat;

c. Undang-Undang/ Peraturan Pemerintah Pengganti Undang-Undang;

d. Peraturan Pemerintah;

e. Peraturan Presiden;

f. Peraturan Daerah Provinsi; dan

g. Peraturan Daerah Kabupaten/Kota.

Hamid Attamimi melakukan identifikasi atas hierarki berdasarkan perundang-undangan Indonesia berdasarkan teori Hans Nawiasky. Attamimi (1990, p. 359) menyimpulkan bahwa hierarki peraturan perundang-undangan Indonesia disusun sebagai berikut:

1. Staatsfundamentalnorm : Pancasila (Pembukaan UUD 1945);

2. Staatsgrundgesetz : Batang Tubuh UUD 1945, Tap MPR, dan Konvensi Ketatanegaraan;

3. Formell gesetz: Undang-Undang atau Peraturan Pemerintah Pengganti UndangUndang;

4. Verordnung en Autonome Satzung : mulai dari Peraturan Pemerintah hingga Keputusan Bupati atau Walikota.

Dalam konteks ini, Bagir Manan (2004, p. 133) menekankan, ada beberapa prinsip yang perlu diperhatikan dalam hierarki norma hukum yang berlaku di Indonesia, yaitu:

1. Peraturan Perundang-undangan yang kedudukannya lebih tinggi dapat digunakan sebagai dasar hukum atau dasar peraturan perundang-undangan yang lebih rendah atau di bawahnya.

2. Peraturan perundang-undangan yang lebih rendah tidak boleh menyimpang atau bertentangan dengan peraturan perundang-undangan yang lebih tinggi darinya.

3. Isi atau muatan peraturan perundang-undangan yang lebih rendah tidak boleh menyimpang atau bertentangan dengan peraturan perundang-undangan yang lebih tinggi.

4. Suatu peraturan perundang-undangan hanya dapat dicabut atau diganti atau diubah dengan peraturan perundang-undangan yang lebih tinggi atau setidak-tidaknya yang sederajat.

5. apabila peraturan perundang-undangan yang sama mengatur materi yang sama, maka peraturan yang terbaru harus ditegakkan, walaupun tidak secara tegas dinyatakan bahwa peraturan yang lama dicabut.

Berkaitan dengan UU No. 5/1999, UU No. 19/2003, UU No. 25/2009, Permen BUMN No. 3/2015, dan Peraturan OJK No. 33/2014, yang mana empat peraturan tersebut mengenai jabatan rangkap Direksi BUMN, apabila dikaitkan dengan hierarki peraturan perundangundangan dan teori Hans Nawiasky, maka secara sederhana dapat digambarkan dalam tabel di bawah ini: 
Tabel 1. Peraturan terkait Legalitas Jabatan Rangkap Direksi BUMN

\begin{tabular}{|c|l|l|l|}
\hline No. & Peraturan Perundang-undangan & $\begin{array}{l}\text { Hierarki } \\
\text { 1. }\end{array}$ & $\begin{array}{l}\text { Undang-Undang } \\
\text { (formallegezetz) }\end{array}$ \\
\hline $\mathbf{2 .}$ & Pasal 25 dan Pasal 33 UU No. 19/2003 & $\begin{array}{l}\text { Undang-Undang } \\
\text { (formallegezetz) }\end{array}$ & Melarang jabatan rangkap \\
\hline $\mathbf{3 .}$ & Pasal 17 huruf a UU No. 25/2009 & $\begin{array}{l}\text { Undang-Undang } \\
\text { (formallegezetz) }\end{array}$ & Melarang jabatan rangkap \\
\hline $\mathbf{4 .}$ & $\begin{array}{l}\text { Lampiran BAB IV huruf A angka 4 } \\
\text { huruf c, angka 5, dan angka 6 Permen } \\
\text { BUMN No. 3/2015 }\end{array}$ & $\begin{array}{l}\text { Peraturan pelaksanaan } \\
\text { (verordnung) }\end{array}$ & $\begin{array}{l}\text { Melarang jabatan rangkap dengan pengecualian izin } \\
\text { Menteri. }\end{array}$ \\
\hline $\mathbf{5 .}$ & $\begin{array}{l}\text { Pasal 6 dan Pasal 24 Peraturan OJK } \\
\text { No. 33/2014 }\end{array}$ & $\begin{array}{l}\text { Peraturan pelaksanaan } \\
\text { (verordnung) }\end{array}$ & $\begin{array}{l}\text { Memperbolehkan jabatan rangkap sepanjang tidak } \\
\text { bertentangan dengan peraturan perundang-undangan } \\
\text { lainnya. }\end{array}$ \\
\hline
\end{tabular}

Berdasarkan tabel di atas dapat dilihat bahwa UU No. 5/1999, UU No. 19/2003 dan UU No. 25/2009 sebagai Undang-Undang (formallegezetz) memiliki hierarki yang lebih tinggi dibandingkan dengan Permen BUMN No. 3/2015 dan Peraturan OJK No. 33/2014 sebagai Peraturan pelaksanaan (verordnung). Inkonsistensi norma antara peraturan perundangundangan yang lebih rendah yaitu peraturan pelaksana yang memperbolehkan jabatan rangkap, namun peraturan diatasnya melarang adanya jabatan rangkap maka dapat dituntut untuk dibatalkan bahkan batal demi hukum (van rechtswege nietig) (Bagir Manan, 2004, pp. 201202). Oleh karena itu, dapat disimpulkan bahwa praktik jabatan rangkap Direksi BUMN dilarang berdasarkan hierarki peraturan perundang-undangan sebagaimana asas "Lex superior derogat legi inferiori" yaitu hukum yang lebih tinggi mengesampingkan hukum yang rendah. Dengan demikian kedudukan dari peraturan terkait jabatan rangkap di Indonesia menunjukan ketidakonsistenan norma secara vertikal yang berdampak pada timbulnya ketidakpastian hukum yang mengatur terkait jabatan rangkap oleh direksi BUMN (Persero) di Indonesia karena antara satu peraturan dengan peraturan yang lainnya saling bertentangan.

\section{Implikasi Praktik Jabatan Rangkap yang Berpengaruh Terhadap Penetapan Harga Tiket Pesawat}

Jabatan rangkap Direksi BUMN merupakan pelanggaran hukum sebagaimana diatur dalam UU No. 5/1999, UU No. 19/2003 dan UU No. 25/2019. Pada praktiknya pelanggaran hukum tersebut dapat dilihat dari kasus yang terjadi antara PT. Garuda Indonesia (Persero) Tbk melalui anak usahanya PT. Citilink Indonesia (Citilink) pada 9 November 2018 mengambil alih pengelolaan operasional dan finansial dari PT. Sriwijaya Air (Sriwijaya) yang terdiri dari maskapai Sriwijaya dan NAM Air melalui Perjanjian Kerjasama Operasi (KSO). Berdasarkan perjanjian tersebut Garuda Group berhak menunjuk perwakilan ke dalam susunan Direksi Sriwijaya, oleh karena itu berkaitan dengan kerjasama tersebut maka secara langsung maupun tidak langsung Garuda Group telah melakukan pengendalian secara operasional terhadap kegiatan usaha Sriwijaya Group (Fajar, 2018).

Kasus ini menarik perhatian publik secara luas karena masyarakat selaku konsumen sangat keberatan dengan adanya kenaikan harga tiket pesawat secara tidak wajar meskipun sudah melewati periode high season di akhir tahun 2018 menjelang tahun 2019. Hal ini mendorong pada terbitnya petisi daring dalam laman change.org berjudul "Turunkan Harga Tiket Pesawat Domestik Indonesia" yang menuai berbagai polemik di masyarakat (Fadhil, 2019). Komisi Pengawas Persaingan Usaha (KPPU) menjelaskan bahwa dalam implementasi perjanjian KSO antara kedua perusahaan penerbangan tersebut diketahui bahwa struktur dewan komisaris Sriwijaya Air berubah, dimana terdapat tiga direksi Garuda Indonesia terbukti merangkap jabatan dengan masuk ke dalam jajaran Dewan Komisaris Sriwijaya Air (Wicaksono, 2019). 
Pasca kesepakatan atas kerjasama operasi antara Garuda dan Sriwijaya, sesuai dengan hasil RUPS Sriwijaya Air, diketahui pada saat yang sama pengurus perusahaan Sriwijaya dijabat oleh pengurus perusahaan Garuda Group yaitu sebagai berikut:

a. I Gusti Ngurah Askhara Danadiputra yang menjabat sebagai Direktur Utama PT Garuda Indonesia (Persero), Tbk. juga menjabat sebagai Komisaris Utama di PT. Citilink Indonesia dan sebagai Komisaris Utama PT. Sriwijaya Air;

b. Pikri Ilham Kurniansyah yang menjabat sebagai Direktur Niaga PT. Garuda Indonesia (Persero), Tbk. juga menjabat sebagai Komisaris di PT. Citilink Indonesia dan sebagai Komisaris di PT. Sriwijaya Air;

c. Juliandra yang menjabat sebagai Direktur Utama PT. Citilink Indonesia juga menjabat sebagai Komisaris di PT. Sriwijaya Air.

Komisioner KPPU, Guntur Syahputra Saragih menegaskan bahwa praktik jabatan rangkap yang terjadi sangat rentan membuat Garuda Indonesia memiliki wewenang lebih pada pengaturan bisnis yang dijalankan Sriwijaya Air (Rika, 2019). Pada dasarnya direksi Garuda Indonesia tidak dapat menempati posisi sejenis di Sriwijaya Air karena kedua perusahaan tersebut berada dalam sektor usaha sejenis atau dalam pasar bersangkutan yang sama sehingga berpotensi menimbulkan persaingan usaha tidak sehat.

Salah satu potensi persaingan usaha tidak sehat yang dapat ditimbulkan dengan adanya praktik jabatan rangkap ialah terkait penetapan harga yang diatur dalam Pasal 5 UU No.5/1999 yang dinyatakan bahwa: "pelaku usaha dilarang membuat perjanjian dengan pelaku usaha pesaingnya untuk menetapkan harga atas suatu barang dan/atau jasa yang harus dibayar oleh konsumen atau pelanggan pada pasar bersangkutan yang sama." Rumusan pasal 5 UU No. 5/1999 secara jelas menegaskan larangan atas perjanjian penetapan harga karena penetapan harga oleh pelaku usaha dengan pelaku usaha pesaingnya secara bersama-sama akan menyebabkan tidak berlakunya hukum pasar terkait harga yang terbentuk dari adanya tawaran dan permintaan (supply and demand). (Andrianti, 2018).

Keterkaitan antara praktik jabatan rangkap dengan penetapan harga ini juga dijelaskan dalam Peraturan Komisi Pengawas Persaingan Usaha No.4 Tahun 2011 tentang Pedoman Penetapan Harga ("Perkom No.4/2011") bahwa perilaku penetapan harga akan menjadi lebih mudah dilakukan apabila terdapat jabatan rangkap yang dilakukan pada perusahaan yang saling bersaing, karena penyalahgunaan posisi tersebut dapat menjadi media yang memfasilitasi proses penetapan harga oleh organ persero yang memiliki kepentingan yang sama.

Tanpa perlu mengadakan penyelidikan lebih lanjut mengenai dampak dan akibat yang ditimbulkan dari penetapan harga maka pendekatan yang digunakan dalam menganalisis indikasi pelanggaran pada perkara ini ialah menggunakan metode pendekatan Per se Illegal. Metode pendekatan tersebut memandang perilaku atau tindakan yang dilakukan bersifat mutlak sebagai perilaku ilegal atau melawan hukum (unlawful act), sehingga Majelis Komisi dalam mempertimbangkan putusan hanya dengan melihat ada atau tidaknya unsur formal atas pelanggaran penetapan harga.

Teori Conscious Parallelism menjelaskan bahwa strategi kesepakatan harga yang dilakukan oleh pelaku usaha dalam struktur pasar oligopoli dilakukan tanpa adanya kesepakatan tertulis antara para pihak yang melakukannya (Vaska, 1985). Dengan demikian pelanggaran yang terjadi dalam hal ini tidak secara khusus dibuktikan dengan adanya perjanjian penetapan harga tertulis oleh pelaku usaha semata, namun juga dapat dilihat dari perilaku pelaku usaha yang sama atau serupa (concerted action atau parallelism).

Pada kasus kenaikan harga tiket Perjanjian tidak tertulis ditunjukkan dengan tindakan bersama atau paralelisme, namun keduanya tidak didasarkan pada perjanjian, dapat pula terjadi tindakan atau tindakan independen dari para pelaku usaha. Oleh karena itu, untuk membuktikan bahwa concerted action atau parallelism merupakan hasil dari perjanjian antara pelaku perlu adanya bukti-bukti lain atau yang dikenal dengan plus factor sehingga dapat dikatakan telah 
terjadi kesepakatan antara pelaku usaha (terjadinya meeting of minds) berdasarkan pemenuhan unsur-unsur perjanjian penetapan harga sebagaimana ditentukan dalam Pasal 5 UU No.5/1999, yaitu sebagai berikut:

a. Unsur Pelaku Usaha dan Pelaku Usaha Pesaing. Dalam ketentuan Pasal 1 angka 5 UU No.5/1999 menentukan bahwa "setiap orang perorangan atau badan usaha, baik yang berbentuk badan hukum yang didirikan dan berkedudukan atau melakukan kegiatan dalam wilayah hukum negara Republik Indonesia, baik sendiri maupun bersama-sama melalui perjanjian, menyelenggarakan berbagai kegiatan usaha dalam bidang ekonomi”. Sedangkan yang dimaksud pelaku usaha pesaing adalah pelaku usaha lain yang berada di dalam satu pasar bersangkutan. Pelaku usaha dan pelaku usaha pesaing dalam kasus ini adalah PT. Garuda Indonesia (Persero) Tbk dan anak perusahaannya PT. Citilink Indonesia (Citilink) dengan PT. Sriwijaya Air (Sriwijaya). Dengan demikian unsur pelaku usaha dan pelaku usaha pesaing terpenuhi.

b. Unsur Perjanjian. Dalam kasus ini diketahui terdapat perjanjian KSO yang secara tidak langsung melahirkan kesepakatan yang menimbulkan praktik jabatan rangkap direksi, kemudian praktik tersebut berpotensi mengatur harga jual ke pasar. Bahwa walaupun tidak terdapat perjanjian tertulis berupa perjanjian penetapan harga oleh para pelaku usaha, melainkan hal ini dapat dilihat dari perilaku pelaku usaha yang sama atau serupa (concerted action atau parallelism) dari para pelaku sehingga dapat dipastikan telah terjadi kesepakatan antar pelaku usaha (meeting of minds) dalam bentuk kesepakatan untuk menghilangkan diskon dan kesepakatan untuk menghilangkan produk yang ditawarkan dengan harga rendah di pasar yang sehingga membatasi dan mempertahankan harga yang tinggi untuk jasa angkutan niaga berjadwal bagi penumpang kelas ekonomi di wilayah Indonesia. Bahwa concerted action atau parallelism pelaku usaha yang didukung plus factors tidak didasarkan pada tindakan independen dari pelaku usaha tetapi berdasarkan kesepakatan meeting of minds di atas. Oleh karena itu, concerted action atau parallelism untuk menurunkan subclass dengan harga murah yang dilakukan oleh pelaku melalui kesepakatan antar pelaku usaha (meeting of minds) menyebabkan kenaikan harga tiket pesawat sehingga konsumen membayar lebih mahal dari biasanya. Dengan demikian, tidak ada kesepakatan yang terpenuhi.

c. Unsur Menetapkan Harga. Penetapan harga merupakan bentuk persekongkolan antar pelaku usaha yang bersaing. Dengan demikian penetapan harga yang dilarang menurut Pasal 5 UU No.5/1999 adalah penetapan harga yang bersumber dari perjanjian. Berdasarkan Perkom No.4/2011, disebutkan bahwa bentuk-bentuk penetapan harga yang termasuk dalam larangan Pasal 5 UU No.5/1999 adalah (d) kesepakatan untuk menghilangkan diskon atau membuat diskon yang seragam dan (f) kesepakatan untuk menghilangkan produk yang ditawarkan dengan harga murah di pasar sehingga membatasi pasokan dan menjaga harga tetap tinggi. Dengan demikian unsur menetapkan harga telah terpenuhi.

d. Unsur Barang dan/atau Jasa. Berdasarkan ketentuan Pasal 1 angka 16 UU No.5/1999 dan Pasal 1 angka 17 UU No.5/1999 yang menjelaskan terkait barang dan/atau jasa, diketahui bahwa frasa barang dan/atau jasa bersifat kumulatif maupun alternatif, yang berarti unsur barang dan jasa harus kedua-duanya terpenuhi atau cukup salah satunya saja, barang atau jasa yang terpenuhi. Dalam kasus ini diketahui bahwa yang dimaksud dengan jasa dalam kasus ini adalah seluruh jenis pelayanan dari para pelaku usaha. Dengan demikian unsur suatu barang dan/atau jasa terpenuhi. 
e. Unsur Konsumen. Berdasarkan ketentuan Pasal 1 angka 15 UU No.5/1999, konsumen adalah setiap pemakai dana atau pengguna barang dan/atau jasa baik untuk kepentingan pribadi maupun untuk kepentingan pihak lain. Konsumen dalam hal ini adalah pengguna jasa angkutan udara niaga berjadwal bagi penumpang kelas ekonomi untuk kepentingan sendiri atau untuk kepentingan pihak lain. Dengan demikian unsur konsumen terpenuhi.

f. Unsur Pasar Bersangkutan yang Sama. Berdasarkan ketentuan Pasal 1 angka 10 Undang-Undang Nomor 5 Tahun 1999, yang dimaksud dengan pasar bersangkutan adalah pasar yang berkaitan dengan jangkauan atau wilayah pemasaran tertentu oleh pelaku usaha untuk barang dan/atau jasa yang sama atau substitusi dari barang dan jasa tersebut. Dengan demikian, pasar yang dimaksud dalam hal ini adalah jasa angkutan udara niaga berjadwal untuk penumpang kelas ekonomi di Indonesia, sehingga unsur pasar bersangkutan yang sama terpenuhi.

Tabel 2. Unsur Penetapan Harga Menurut Pasal 5 UU No. 5/1999

\begin{tabular}{|c|c|c|}
\hline No. & Unsur & Unsur Terpenuhi \\
\hline 1. & Pelaku usaha & $\begin{array}{l}\text { PT. Garuda Indonesia, PT. Citilink Indonesia, PT. Sriwijaya Air (Sriwijaya), PT NAM Air, PT } \\
\text { Batik Air Indonesia, PT Lion Mentari, dan PT Wings Abadi. }\end{array}$ \\
\hline 2. & Perjanjian & $\begin{array}{l}\text { Hasil kesepakatan antar pelaku usaha (meeting of minds), yang didukung oleh plus factors } \\
\text { berupa persamaan perilaku para pelaku usaha. }\end{array}$ \\
\hline 3. & Menetapkan Harga & $\begin{array}{l}\text { Para pelaku usaha secara bersamaan menjaga harga tinggi pada layanan jasa angkutan udara } \\
\text { niaga penerbangan domestik kelas ekonomi yang tidak mengikuti permintaan peak season dan } \\
\text { low season. }\end{array}$ \\
\hline 4. & Barang dan/atau Jasa & Seluruh jenis pelayanan dari para pelaku usaha. \\
\hline 5. & Konsumen & Setiap penumpang kelas ekonomi jasa layanan angkutan udara niaga. \\
\hline 6. & $\begin{array}{l}\text { Pasar Bersangkutan yang } \\
\text { Sama }\end{array}$ & $\begin{array}{l}\text { Jasa angkutan udara niaga berjadwal dan saling tersubstitusi untuk penumpang kelas ekonomi } \\
\text { di Indonesia untuk setiap rute penerbangan. }\end{array}$ \\
\hline
\end{tabular}

Sumber: Putusan 15/KPPU-I/2019

Berdasarkan analisis pemenuhan unsur-unsur formal penetapan harga berdasarkan Pasal 5 UU No.5/1999 maka diketahui baik PT. Garuda Indonesia bersama anak perusahaannya PT. Citilink Indonesia dengan PT. Sriwijaya Air terbukti secara sah dan meyakinkan telah melanggar ketentuan Pasal 5 UU No.5/1999 tentang Penetapan Harga. Potensi besar terjadinya penetapan harga akibat jabatan rangkap pada kasus ini semakin diperkuat dengan adanya ketidakpastian hukum yang mengatur terkait peraturan jabatan rangkap Direksi BUMN (Persero) yang mana dari penelitian peraturan terkait jabatan rangkap di Indonesia menunjukan ketidakonsistenan norma antara peraturan satu dengan peraturan lainnya.

Kesamaan perilaku para pelaku usaha yang secara tidak langsung untuk menetapkan harga pada kasus ini bersifat horizontal karena dilakukan secara bersama-sama antara sesama pelaku usaha yang selevel pada pasar bersangkutan yang sama (khususnya Garuda Group dengan Sriwijaya Group). Kesepakatan yang dilakukan secara bersamaan ini terbukti dengan adanya concerted action atau parallelism oleh para pelaku usaha melalui berbagai cara seperti secara bersamaan melakukan pencabutan izin rute atau pengurangan frekuensi pesawat subclass dengan harga murah, meniadakan diskon atau membuat keseragaman diskon, serta kesepakatan meniadakan produk yang ditawarkan dengan harga murah di pasar.

Memperhatikan berbagai fakta-fakta yang telah disebutkan di atas, kemudian pada hal ini perilaku-perilaku tersebut dinilai sebagai suatu kesepakatan tidak tertulis antara para pelaku usaha atau meeting of minds yang pada akhirnya menyebabkan mahalnya harga tiket pesawat yang harus dibayarkan konsumen. Dengan demikian dapat disimpulkan bahwa implikasi praktik jabatan rangkap oleh Direksi BUMN (Persero) yang dalam kasus ini dilakukan oleh Direksi dari PT. Garuda Indonesia berpotensi menimbulkan persaingan usaha tidak sehat karena penetapan harga tiket pesawat bukan bersumber dari pertimbangan nilai keekonomisan tetapi adanya kepentingan yang sama dari organ persero. Dengan demikian dapat disimpulkan 
bahwa melalui praktik jabatan yang dilakukan oleh Direksi BUMN ini kemudian dapat menjadi media yang memfasilitasi terjadinya penetapan harga yang berdampak pada kenaikan harga tiket pesawat sejak akhir tahun 2018 hingga awal tahun 2019.

\section{KESIMPULAN DAN SARAN}

\section{Kesimpulan}

1. Kedudukan dari peraturan terkait jabatan rangkap di Indonesia menunjukan ketidakonsistenan norma secara vertikal yang berdampak pada timbulnya ketidakpastian hukum yang mengatur terkait oleh jabatan rangkap direksi BUMN (Persero) di Indonesia karena peraturan-peraturannya saling bertentangan satu sama lain. Peraturan Menteri BUMN No.3/2015 dan Peraturan OJK No.33/2014 yang berkedudukan lebih rendah dari Undang-Undang memperbolehkan praktik jabatan rangkap direksi BUMN (Persero) dengan pengecualian, namun UU No.5/1999, UU No.19/2003 dan UU No.25/2009 yang berkedudukan lebih tinggi melarang praktik jabatan rangkap tersebut. Menurut teori Hans Nawiasky, peraturan pelaksanaan (verordnung) yang memiliki hierarki yang lebih rendah dibandingkan dengan Undang-Undang (formallegezetz) tersebut dapat dituntut untuk dibatalkan bahkan batal demi hukum (van rechtswege nietig). Oleh karenanya, dapat disimpulkan bahwa telah terjadi ketidakpastian hukum terkait jabatan rangkap direksi BUMN serta legalitas jabatan rangkap Direksi BUMN dilarang berdasarkan hierarki peraturan perundang-undangan sebagaimana asas "Lex superior derogat legi inferiori" yaitu hukum yang lebih tinggi mengesampingkan hukum yang rendah.

2. Keterkaitan praktik jabatan rangkap direksi BUMN terhadap pelanggaran perjanjian harga termaktub dalam Perkom No.4/2011, yang mana perilaku penetapan harga akan menjadi lebih mudah dilakukan apabila terdapat seseorang yang memiliki jabatan rangkap pada perusahaan yang saling bersaing. Adanya pengaruh praktik jabatan rangkap ini dapat mengakibatkan penetapan harga bukan bersumber dari pertimbangan nilai keekonomisan tetapi adanya kepentingan yang sama dari organ Persero. Teori conscious parallelism menjelaskan strategi penetapan harga dapat dilakukan tanpa adanya perjanjian tertulis oleh para pelaku usaha, namun dapat dilihat dari perilaku pelaku usaha yang sama atau mirip (concerted action atau parallelism). Hal ini sebagaimana terjadi pada kasus yang terjadi antara PT. Garuda Indonesia (Persero) Tbk melalui anak usahanya PT. Citilink Indonesia (Citilink) dan PT. Sriwijaya Air yang berawal dari Perjanjian Kerjasama Operasi (KSO). Dengan demikian praktik jabatan rangkap Direksi BUMN (Persero) telah mempengaruhi timbulnya penetapan harga tiket pesawat yang terjadi pada tahun 2019.

\section{Saran}

1. Mengingat terdapat inkonsistensi peraturan jabatan rangkap pada Peraturan Menteri Badan Usaha Milik Negara (BUMN) dan Otoritas Jasa Keuangan (OJK), maka Lembaga terkait perlu melakukan sinkronisasi norma hukum yang ada agar bersumber dan berdasar dari norma yang lebih tinggi dalam hal ini Undang-Undang agar tercipta kepastian hukum dari peraturan jabatan rangkap dan mencapai tujuan dari UU BUMN itu sendiri guna mengelola perusahaan yang professional tanpa adanya benturan kepentingan.

2. Lembaga Legislatif perlu melakukan peninjauan kembali pada implementasi dari pengaturan terkait jabatan rangkap di Indonesia dan mengharmonisasikan Undangundang dengan peraturan dibawahnya yang ada secara jelas dan tegas agar peraturannya tidak saling bertentangan antara peraturan satu dengan peraturan yang lainnya. Dengan 
demikian dapat menghindari adanya potensi persaingan usaha tidak sehat yang timbul akibat adanya praktik jabatan rangkap seperti yang terjadi pada kasus ini.

\section{DAFTAR PUSTAKA}

Adhi Wicaksono, "KPPU Panggil Menteri BUMN soal Rangkap Jabatan Direksi Garuda", diakses melalui https://www.cnnindonesia.com/ekonomi/20190715173805-92412314/kppu-panggil-menteri-bumn-soal-rangkap-jabatan-direksi-garuda diakses pada 25 Agustus 2020.

Andrianti, Endang. (2018). Perjanjian Penetapan Harga Gula Impor Indonesia (Studi Putusan Perkara Nomor: 08/KPPU-I/2015). Jakarta: Jurnal Ilmiah FH Universitas Mataram.

Anggraini, Anna Maria Tri, et.al. (2017). Hukum Persaingan Usaha. Jakarta: Komisi Pengawas Persaingan Usaha (KPPU).

Astawa, I Gde Pantja. (2008). Dinamika Hukum dan Ilmu Perundang-undangan di Indonesia. Bandung: PT. Alumni.

Haris Fadhil, "Komisi V Panggil Kemenhub Soal Harga Tiket Pesawat”, diakses melalui https://news.detik.com/berita/d-4381341/komisi-v-panggil-kemenhub-soal-harga-tiketpesawat-pekan-depan? ga=2.213547664.50731333.16063123191613573531.1601439338 , diakses pada 25 Agustus 2020.

Hermansyah. (2009). Pokok-Pokok Hukum Persaingan Usaha di Indonesia. Jakarta: Kencana Prenada Media Group.

Hesti Rika, "KPPU Selidiki Rangkap Jabatan Bos Garuda di Sriwijaya Air", diakses melalui https://www.cnnindonesia.com/ekonomi/20190212092746-92-368422/kppu-selidikirangkap-jabatan-bos-garuda-di-sriwijaya-air, diakses pada 25 Agustus 2020.

Ismail, Nurhasan. (2007). Perkembangan Hukum Pertanahan: Pendekatan Ekonomi Politik. Yogyakarta: Universitas Gajah Mada.

Kitab Undang-Undang Hukum Perdata (KUHPerdata).

Komisi Pengawas Persaingan Usaha (KPPU), Dugaan Pelanggaran Pasal 5 Dan Pasal 11 UU Nomor 5 Tahun 1999 Terkait Jasa Angkutan Udara Niaga Berjadwal Penumpang Kelas Ekonomi Dalam Negeri, Perkara Nomor 15/KPPU-I/2019, 23 Juni 2020.

Lubis, Andi Fatmi, et.al. (2009). Hukum Persaingan Usaha Anatar Teks dan Konteks. Jakarta: Deutsche Gesellschaft für Technische Zusammenarbeit (GTZ) GmbH.

Manan, Bagir. (2004). Teori dan Politik Konstitusi. Yogyakarta: FH UII Press.

Margono, Suyud. (2009). Hukum Anti Monopoli. Jakarta: Sinar Grafika.

Michale K Vaska, "Conscious Parallelism and Price Fixing: Defining the Boundary”, diakses melalui

https://chicagounbound.uchicago.edu/cgi/viewcontent.cgi?article $=4411 \&$ context $=$ uclre v diakses pada 28 April 2021.

Peraturan Komisi Pengawas Persaingan Usaha Nomor 4 Tahun 2011 tentang Pedoman Penetapan Harga.

Peraturan Komisi Pengawas Persaingan Usaha Nomor 7 Tahun 2009 tentang Pedoman Jabatan Rangkap.

Peraturan Menteri Badan Usaha Milik Negara Nomor PER-03/MBU/02/2015 Tentang Persyaratan, Tata Cara Pengangkatan dan Pemberhentian Anggota Direksi Badan Usaha Milik Negara.

Peraturan Otoritas Jasa Keuangan Nomor 33/POJK.04/2014 Tentang Direksi dan Dewan Komisaris Emiten Atau Perusahaan Publik.

Soekanto, Soerjono dan Mamudji, Sri. 2001. Penelitian Hukum Normatif (Suatu Tinjauan Singkat). Jakarta: Rajawali Pers. 
Syamsuddi, Aziz. (2011). Proses Dan teknik Penyusunan Undang-undang. Cetakan Pertama. Jakarta: Sinar Grafika.

Taufik Fajar, "Garuda Indonesia Ambil Alih Operasional Sriwijaya Group", diakses melalui https://economy.okezone.com/read/2018/11/15/320/1978041/garuda-indonesia-ambilalih-operasional-sriwijaya-group, diakses pada 25 Agustus 2020.

Undang-Undang Dasar Negara Republik Indonesia Tahun 1945.

Undang-Undang Nomor 15 Tahun 2019 Tentang Perubahan Atas Undang-Undang Nomor 12 Tahun 2011 Tentang Pembentukan Peraturan Perundang-undangan.

Undang-Undang Nomor 19 Tahun 2003 Tentang Badan Usaha Milik Negara.

Undang-Undang Nomor 25 Tahun 2009 Tentang Pelayanan Publik.

Undang-Undang Nomor 40 Tahun 2007 Tentang Perseroan Terbatas.

Undang-Undang Nomor 5 Tahun 1999 Tentang Larangan Praktek Monopoli dan Persaingan Usaha Tidak Sehat.

Usman, Rachmadi. (2013). Hukum Persaingan Usaha di Indonesia. Jakarta: Sinar Grafika.

Wignjosoebroto, Soetandyo. (2013). Hukum Konsep dan Metode. Jakarta: Setara Press. 